\title{
Rangelia vitalii and Hepatozoon canis coinfection in pampas fox Lycalopex gymnocercus from Santa Catarina State, Brazil
}

\author{
Infecção por Rangelia vitalii e Hepatozoon canis em Lycalopex gymnocercus proveniente do \\ Estado de Santa Catarina, Brasil
}

Maria Regina Lucas da Silva ${ }^{1}$; Cláudio Roberto Scabelo Mattoso ${ }^{2}$; Adson Costa ${ }^{3}$; Mere Erika Saito ${ }^{3}$; Lygia Tchaicka ${ }^{4}$; Lucia Helena O’Dwyer ${ }^{1 *}$

\author{
${ }^{1}$ Departamento de Parasitologia, Instituto de Biociências, Universidade Estadual Paulista - UNESP, Botucatu, SP, Brasil \\ ${ }^{2}$ Departamento de Clínica e Cirurgia Veterinárias, Escola de Veterinária, Universidade Federal de Minas Gerais - UFMG, Belo \\ Horizonte, MG, Brasil \\ ${ }^{3}$ Departamento de Medicina Veterinária, Centro de Ciências Agroveterinárias - CAV, Universidade do Estado de Santa Catarina - \\ UDESC, Lages, SC, Brasil \\ ${ }^{4}$ Centro de Ciências Exatas e Naturais, Universidade Estadual do Maranhão - UEMA, São Luis, MA, Brasil
}

Received November 16, 2017

Accepted February 2, 2018

\begin{abstract}
Rangelia vitalii is a haemoparasite that infects erythrocytes, white blood cells and the cytoplasm of endothelial cells of blood capillaries of canids in South America, and has been detected in both domestic dogs and sylvatic canids. Hepatozoon canis is a parasite that infects neutrophils and monocytes of many mammalian hosts. This study reports the infection of Lycalopex gymnocercus from Santa Catarina, Brazil, with $R$. vitalii and H. canis. The piroplasm was observed on both blood smears and molecular tests. Many large piroplasms were detected inside the erythrocytes, with round, oval, or teardrop-shaped organism, that occurred singly or in pairs. They had an abundant, pale blue cytoplasm and decentral dark red small nucleus. The animal was also infected with $H$. canis that was detected only by molecular tests. The majority of haematological and biochemistry parameters were within the reference values for domestic dog and wild canids.
\end{abstract}

Keywords: Haemoparasites, molecular characterization, piroplasm, sylvatic canid.

\section{Resumo}

Rangelia vitalii é um hemoparasita que infecta eritrócitos, macrófagos e células endoteliais de canídeos na América do Sul, e vem sendo detectado tanto em cães domésticos quanto em canídeos silvestres. Hepatozoon canis é um parasita que infecta monócitos e neutrófilos de mamíferos. No presente estudo, é descrita a infecção de Lycalopex gymnocercus, proveniente de Santa Catarina, Brasil, por $R$. vitalii e H. canis. O piroplasma foi diagnosticado nos esfregaços sanguíneos e por técnicas moleculares. Nos eritrócitos foram observados vários merozoítos grandes, ovais, arredondados ou em forma de gota, ocorrendo isoladamente ou em pares. Estes piroplasmas apresentavam citoplasma abundante, corado em azul claro, com núcleo pequeno, avermelhado e descentralizado. $\mathrm{O}$ animal apresentou coinfecção com $H$. canis, que foi diagnosticado somente pelos testes moleculares. A maior parte dos parâmetros hematológicos e bioquímicos do animal estava dentro dos valores de referência para cães domésticos e canídeos silvestres.

Palavras-chave: Hemoparasitas, caracterização molecular, piroplasmas, canídeos silvestres.

\section{Introduction}

Rangelia vitalii was first described by Pestana (1910a, b) as a previously unknown piroplasm from dogs, named Piroplasma vitalii. This parasite was later named Rangelia vitalii by Carini \& Maciel

*Corresponding author: Lucia Helena O'Dwyer. Departamento de Parasitologia, Instituto de Biociências, Universidade Estadual Paulista UNESP, Campus de Botucatu, Rua Prof. Dr. Antônio Celso Wagner Zanin, 250, Distrito de Rubiāo Junior, CEP 18618-689, Botucatu, SP, Brasil. e-mail: odwyer@ibb.unesp.br
(1914). Despite the fact that $R$. vitalii has been described since the early 1900s, the species status was only recently confirmed by molecular and transmission studies (SOARES et al., 2011; LEMOS et al., 2012). This protozoan is transmitted by the ixodid tick Amblyomma aureolatum (FRANÇA et al., 2010) and cannot be distinguished from Babesia sp. infection in erythrocytes.

Canine rangeliosis has been reported in South America in domestic dogs in the south eastern and southern regions of Brazil (LORETTI 
\& BARROS, 2005; FRANÇA et al., 2010; LEMOS et al., 2012; MOREIRA et al., 2013), Argentina (EIRAS et al., 2014), and Uruguay (SOARES et al., 2015), and was also found to infect sylvatic canids. For example, Soares et al. (2014) detected the infection in Cerdocyon thous (crab-eating foxes) from Rio Grande do Sul and São Paulo using polymerase chain reaction (PCR), as no piroplasms were found by microscopic examination. In the same study, none of the four Lycalopex gymnocercus (pampas foxes) examined were found to be positive for R.vitalii (SOARES et al., 2014). Quadros et al. (2015) detected $R$. vitalii and Hepatozoon canis in L. gymnocercus from Santa Catarina; however, these parasites were not detected in blood smears. Recently, in Minas Gerais state, the parasite was found to infect the cytoplasm of endothelial cells from a free-ranging Chrysocyon brachyurus (maned wolf) that was co-infected with many parasites, including Hepatozoon sp. (SILVEIRA et al., 2016).

Hepatozoon species are blood parasites that infect a wide range of intermediate vertebrate hosts and its gamonts are observed inside neutrophils and monocytes of mammalian hosts (SMITH, 1996). In Brazil, Hepatozoon spp. have been reported to infect a variety of Carnivora species, including domestic dogs and wild canids (ALENCAR et al., 1997; CRIADO- FORNELIO et al., 2006; ANDRÉ et al., 2010; GIANNITTI et al., 2012; ALMEIDA et al., 2013; SILVEIRA et al., 2016).

In this study, we describe the detection of $R$. vitalii on blood smears, with molecular confirmation, and molecular detection of H. canis in L. gymnocercus from Santa Catarina, Brazil. We also present haematological data for the animal.

\section{Materials and Methods}

A free ranging L. gymnocercus, adult male, was found injured after being hit by a car in Lages, Santa Catarina, Brazil, in July 2014. The animal was taken to the Veterinary Hospital of the Agroveterinary Sciences Center (CAV), Santa Catarina State University (UDESC), where it was examined. The animal showed decreased consciousness (somnolence) and had moderate dehydration.

Approximately $10 \mathrm{~mL}$ blood was collected from the jugular vein after physical examination. Blood smears were prepared immediately after blood sample collection and were stained using both the Diff-Quik Staining System (Laborclin) and Giemsa 10\%. Diagnosis was made based on the examination of slides under a light microscope, at $1000 \times$ magnification. The remaining blood was frozen at $-20{ }^{\circ} \mathrm{C}$ for molecular examination. Parasitaemia was calculated by counting at least 500 red blood cells (number of infected red blood cells / total red blood cells counted $\times 100)($ CONRAD et al., 2006). The detected parasites were identified, and their length and width were measured in a computerized image analysis system using Qwin Lite 2.5 software (Leica). The animal died of the injuries sustained from being hit by the car, but the necropsy was not done.

Red blood cell (RBC) and white blood cell (WBC) counts and haemoglobin concentrations were analysed in an automatic counter (CC510-Celm; Barueri) using the impedance method. The packed cell volume (PCV) was measured by the microhaematocrit procedure (JAIN, 1986). Differential leukocyte counts as well as search for blood parasites were performed on blood smears. The mean corpuscular volume (MCV) and mean corpuscular haemoglobin concentration (MCHC) were calculated. The platelet count was analysed using a haemocytometer chamber (Neubauer chamber) with $1 \%$ ammonium oxalate solution as the diluent. Total plasma protein (TPP) and specific gravity (urine) were measured by refractometry (Digit-Biosystems).

To analyse the biochemical parameters (urea, creatinine, serum total protein [TP], albumin [Alb], and globulin [Glob]), blood (kept in a glass bottle without anticoagulant) was centrifuged at $1,710 \times g$, and the serum was obtained. The serum was used at several biochemical dosages prepared using a semi-automatic device (TP Analyzer Plus; Thermo Plate, São Paulo, Brazil) with the support of commercial kits (Labtest; Minas Gerais, Brazil).

To confirm the identity of the fox species, as some doubts could occur about the morphological characteristics between L. gymnocercus and Lycalopex vetulus, we performed molecular for species barcoding. For that purpose, genomic DNA was extracted from blood using the standard phenol/chloroform protocol (SAMBROOK et al., 1989). The 5' portion of the mitochondrial DNA (mtDNA) control region was amplified by PCR (SAIKI et al., 1985) using primers MTLPRO2 and CCR-DR1 primers (TCHAICKA et al., 2007). Products were examined on a $1 \%$ agarose gels stained with ethidium bromide, purified using polyethylene glycol, sequenced with $\mathrm{ABI}$ chemistry, and analysed with an ABI-PRISM 3100 automated sequencer (Applied Biosystems, Foster City, CA, USA).

DNA extraction for haemoparasite detection was performed from 200- $\mu$ L aliquots of blood using a GFX Genomic Blood DNA Purification kit (GE Healthcare, Buckinghamshire, UK), according to the manufacturer's instructions. Each DNA sample was dissolved in $100 \mu \mathrm{L}$ elution buffer.

Molecular identification of $R$. vitalii through nested PCR was based on amplification of 18S $r D N A$ using the primers BT18SF1/BT18SR1 and BT18SF2/BT18SR2 (PAPARINI et al., 2012). Nested PCR was performed in a total volume of $25 \mu \mathrm{L}$ containing $12.5 \mu \mathrm{L}$ GoTaq Colorless Master Mix (Promega Corporation, WI, USA), 10 pmol of each primer, $1 \mu \mathrm{L}$ DNA or primary PCR amplicon, and $9.5 \mu \mathrm{L}$ ultrapure sterile water. The PCR conditions for the primary PCR (primers BT18SF1/BT18SR1) consisted of a pre-PCR step of $95^{\circ} \mathrm{C}$ for $5 \mathrm{~min}$; followed by 40 cycles of $94^{\circ} \mathrm{C}$ for $30 \mathrm{~s}, 52^{\circ} \mathrm{C}$ for $30 \mathrm{~s}$, and $72^{\circ} \mathrm{C}$ for $2 \mathrm{~min}$; and a final extension of $72^{\circ} \mathrm{C}$ for $7 \mathrm{~min}$. The PCR conditions of the secondary PCR (primers BT18SF2/BT18SR2) consisted of a pre-PCR step of $95^{\circ} \mathrm{C}$ for $5 \mathrm{~min}$; followed by 40 cycles of $94^{\circ} \mathrm{C}$ for $30 \mathrm{~s}, 50{ }^{\circ} \mathrm{C}$ for $30 \mathrm{~s}$, and $72{ }^{\circ} \mathrm{C}$ for $80 \mathrm{~s}$; and a final extension of $72^{\circ} \mathrm{C}$ for $7 \mathrm{~min}$ (PAPARINI et al., 2014).

DNA samples were also screened for the presence of Hepatozoon-specific 18S rDNA by PCR using the 4558 and 2733 primers pair, which amplifies 1120 bp (MATHEW et al., 2000). Conventional PCR were also performed in a total volume of $25 \mu \mathrm{L}$ containing 12.5 $\mu \mathrm{L}$ GoTaq Colorless Master Mix (Promega Corporation), $12.5 \mathrm{pmol}$ of each primer, $5 \mu \mathrm{L}$ DNA, and $5 \mu \mathrm{L}$ ultrapure sterile water. The cycling conditions for the primers 4558 and 2733 were as follows: $94^{\circ} \mathrm{C}$ for $3 \mathrm{~min}$; followed by 40 cycles of $94^{\circ} \mathrm{C}$ for $1 \mathrm{~min}, 56^{\circ} \mathrm{C}$ for $1 \mathrm{~min}$, and $72^{\circ} \mathrm{C}$ for $90 \mathrm{~s}$; and a final extension for $7 \mathrm{~min}$ at $72{ }^{\circ} \mathrm{C}$, with a $4{ }^{\circ} \mathrm{C}$ hold.

In each PCR assay, a negative control (distilled sterile water) was used for both reactions. For positive control for $R$. vitalii, a Babesia vogeli DNA isolated from a naturally infected dog was used, and for $H$. canis was used a DNA isolated from another $H$. canis naturally infected dog.

Aliquots of $3 \mu \mathrm{L}$ of amplified products were analysed on $1 \%$ agarose gels with gel Red (Uniscience) by electrophoresis at 
$80 \mathrm{~V}$ for $60 \mathrm{~min}$ in TAE buffer and visualized under an ultraviolet transilluminator. PCR fragments were estimated by comparison with known amounts of eletrophoretic standards using a $1 \mathrm{~kb}$ plus DNA ladder (Invitrogen, Carlsbad, CA, USA).

The total remaining reaction products were purified using Illustra ExoProStar 1-Step (GE Healthcare) according to the manufacturer's recommendations and sequenced using a BigDye v.3.1 Terminator Cycle Sequencing Ready Reaction Kit (Applied Biosystems) with an automated Applied Biosystems ABI 3500 DNA genetic analyser.

The obtained sequences were edited using BioEdit software, version 7.2.5 (HALL, 1999) and compared for similarity to the sequences deposited in GenBank using BLAST (ALTSCHUL et al., 1990). CLUSTAL X (LARKIN et al., 2007) was used to align the sequences obtained in this study with sequences retrieved from GenBank. The jModelTest v.2.1.10 (DARRIBA et al., 2012) was used to identify the best evolutionary model, according to the Akaike information criterion. GTR+I+G and GTR+G were the models chosen for phylogenetic reconstruction of piroplasm and Hepatozoon spp. sequences, respectively. Phylogenetic trees were construed by Bayesian Inference using MrBayes 3.1.2 (RONQUIST \& HUELSENBECK, 2003). Markov chain Monte Carlo (MCMC) simulations were run for $10^{7}$ generations in two parallel runs, with sampling of trees at 1000 -generation intervals and a burn-in of $25 \%$. Phylogenetic trees were visualized in FigTree v.1.4.3 (TREE BIO, 2016).

\section{Results}

Phylogenetic analysis of the fox mtDNA generated a tree topology in which our sample was highly supported (bootstrap value: 100) as L. gymnocercus. The sequence generated for this study has been deposited in NCBI GenBank database (accession number KX618693). In addition to this sequence, previously published sequences of Lycalopex genera (NCBI GenBank accession numbers JX890309-JX890389) and sequences of $C$. thous (used as outgroup) (TCHAICKA et al., 2007) were included in the analyses. Eighty-one individuals representing all known species of this genus were included. Phylogenetic analysis excluded the possibility of misidentification with $L$. vetulus or $C$. thous, other Brazilian canids showing similar morphology. These species were grouped in different clades with confidence (bootstrap values $>98$ ) (data not demonstrated).

Many large piroplasms were detected inside the erythrocytes (Figures 1A, B) and were initially confounded with B. vogeli. The parasitaemia was calculated as $1.2 \%$ of infected cells. The intra-erythrocytic merozoites of this piroplasm were round, oval, or teardrop-shaped organisms occurring singly or in pairs. The organisms had an abundant, pale blue cytoplasm and decentral dark red small nucleus. The oval shapes measured $3.4 \pm 0.4 \mu \mathrm{m}$ (minimum: 2.79; maximum: 4.58) long and $3.1 \pm 0.35 \mu \mathrm{m}$ (minimum: 2.48; maximum: 4.1) wide. The teardrop shapes were less common and measured $3.0 \pm 0.3 \mu \mathrm{m}$ (minimum: 2.3; maximum: 3.36$)$ long and $2.1 \pm 0.25 \mu \mathrm{m}$ (minimum: 1.7 ; maximum: 2.5 ) wide. Gamonts of $H$. canis were not found on blood smears.

The blood and urine evaluations demonstrated a low platelet count $\left(50 \times 10^{9} / \mathrm{L}\right)$ (normal range $200-500 \times 10^{9} / \mathrm{L}$ ), total protein $(41.2 \mathrm{~g} / \mathrm{L})($ normal range $54-71 \mathrm{~g} / \mathrm{L})$, and albumin $(21.1 \mathrm{~g} / \mathrm{L})$ (normal range $26-33 \mathrm{~g} / \mathrm{L})$ and a high urea concentration $(41.91 \mathrm{mmol} / \mathrm{L})$ (normal range 7.64-21.41 $\mathrm{mmol} / \mathrm{L}$ ). Reference range refers to domestic dogs due to lack of normal values for L. gymnocercus. The other parameters were in accordance with the normal values to domestic dogs (JAIN, 1993; KANEKO et al., 1997) and wild canids (MATTOSO et al., 2012).

According to the PCR results, the blood sample was positive for piroplasm and Hepatozoon spp. The nucleotide sequence of the piroplasm isolate from the blood of L. gymnocercus showed 99\% genetic similarity to R. vitalii (KF218605 and KF218606) from Canisfamiliaris of Argentina by BLASTn analysis and grouped in the same clade with $R$. vitalii sequences obtained from dogs and wild animals in the phylogenetic tree (Figure 2). The Hepatozoon sequence showed $100 \%$ similarity to $H$. canis (AY150067) isolated from a fox of Spain and $100 \%$ to $H$. canis (KU569158) isolated from a Brazilian dog. In addition, phylogenetic analysis showed that the $H$. canis sequence detected in this study grouped in the clade composed of $H$. canis parasites with $97 \%$ probability (Figure 3 ). Rangelia vitalii and $H$. canis sequences were deposited in GenBank (KX816959 and KX816958).
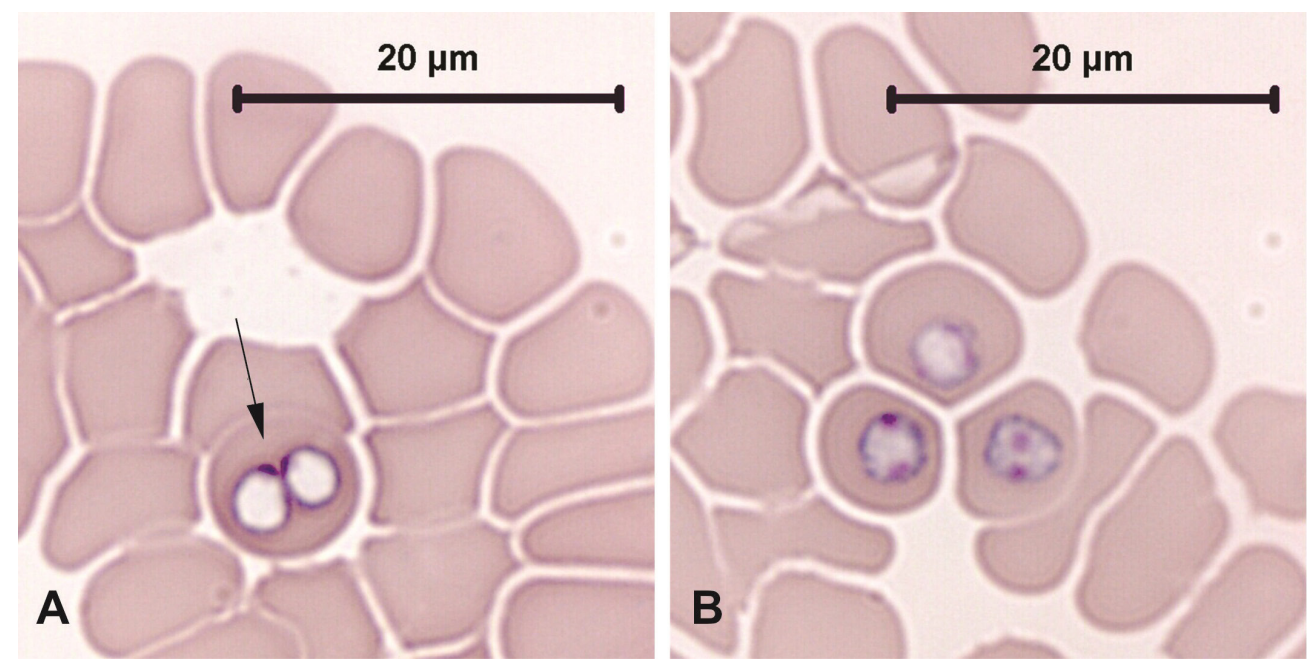

Figure 1. Rangelia vitalii on blood smear of Lycalopex gymnocercus from Santa Catarina state, Brazil. (A) teardrop forms; (B) three oval dividing form, with two nuclei. Scale bars $=20 \mu \mathrm{m}$. (Blood smear, Giemsa). 


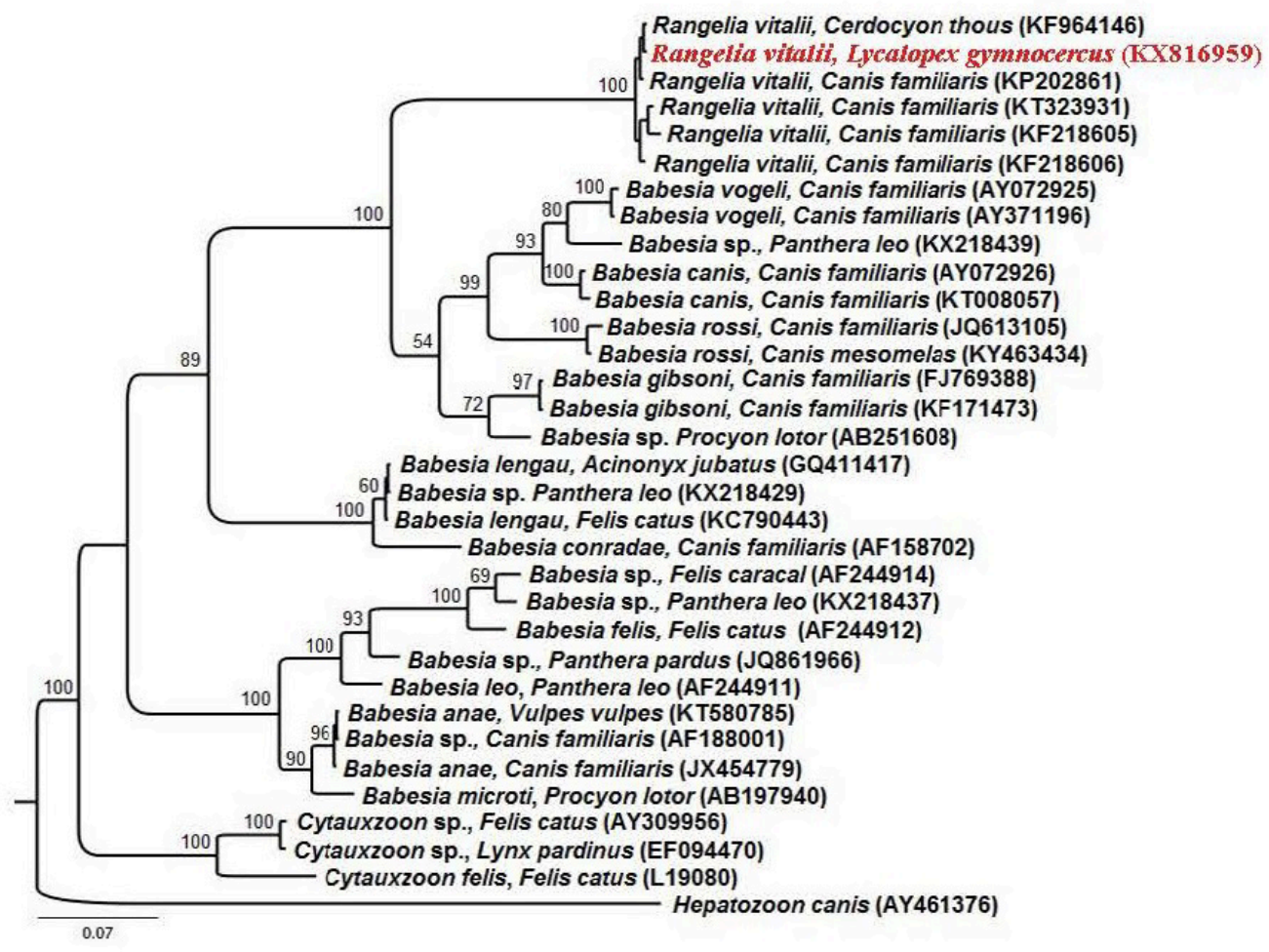

Figure 2. Bayesian Inference (BI) tree based on the $18 \mathrm{~S}$ rRNA gene partial sequences (528bp) of Rangelia vitalii, isolates from Brazilian Lycalopex gymnocercus, and other hemoparasites, using GTR + I + G evolutionary model Hepatozoon canis was chosen as outgroup. Numbers at the nodes indicate posterior probabilities under BI. Posterior probabilities lower than 50 are not shown. The sequence obtained in this study is in red.

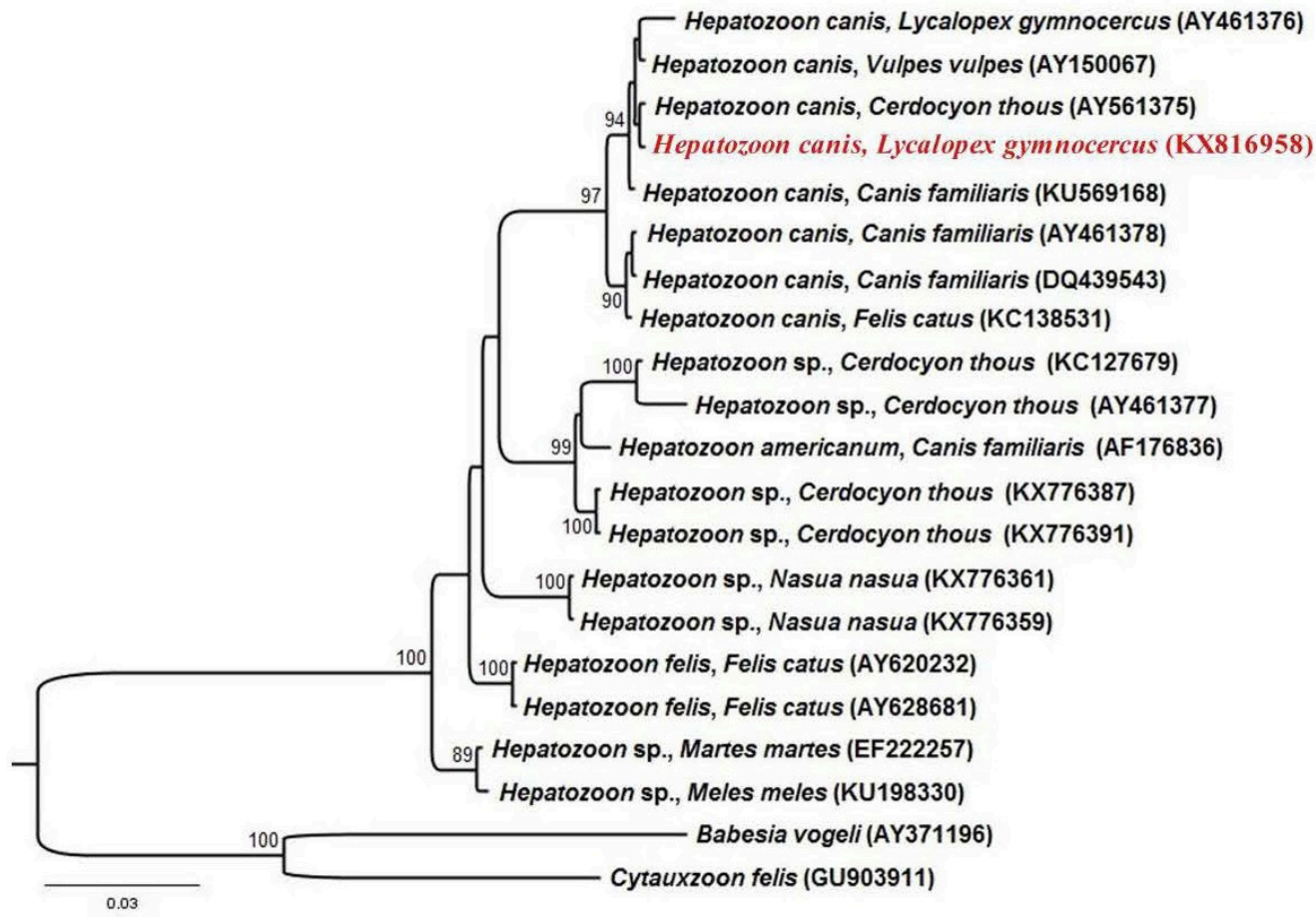

Figure 3. Bayesian Inference (BI) tree based on the $18 \mathrm{~S}$ rRNA gene partial sequences (629bp) of Hepatozoon canis, isolates from Brazilian Lycalopex gymnocercus, and other Hepatozoon spp., using GTR + G evolutionary model. Cytauxzoon felis and Babesia vogeli were chosen as outgroups. Numbers at the nodes indicate posterior probabilities under BI. Posterior probabilities lower than 50 are not shown. The sequence obtained in this study is in red. 


\section{Discussion}

Rangelia vitalii has been detected in sylvatic Brazilian canids since 2014 when Soares et al. (2014) detected, by PCR, nine C. thous positive for $R$. vitalii. Subsequently, this parasite was also found in L. gymnocercus (QUADROS et al., 2015; FREDO et al., 2015). The first detection of this protozoan in wild canids was described by Ruas et al. (2003), who initially identified the parasite as Babesia sp. in L. gymnocercus from southern Brazil. The authors showed that the only tick species found to infest the infected animal was $A$. aureolatum, the natural vector of $R$. vitalii; besides, the known vector of Babesia vogeli, Rhipicephalus sanguineus, was not observed parasitizing the examined animals (RUAS et al., 2003). Nevertheless, at that time, there was no molecular confirmation of the piroplasm identity.

In this study, we showed, for the first time, the intraerythrocytic stages of $R$. vitalii in a wild canid from Brazil. Those stages were similar in form and size to those described in natural and experimentallly infected dogs (SILVA et al., 2011; FRANÇA et al., 2014). The observation of $R$. vitalii in erythrocytes is a rare event, and parasitaemia is typically low when it is detected (SILVA et al., 2011). In experimentally infected dogs, $R$. vitalii merozoites were first detected in blood smears within 5 days of infection, with the peak of parasitaemia from days 9 and 11 post infection. The parasites were then decreased in negative smears until 21 days after infection (SILVA et al., 2011). Our canid was probably in the acute stage of infection as parasitaemia was high $(1.2 \%)$, and many different forms were observed in the erythrocytes, but not in leucocytes.

Laboratory findings of natural cases of canine rangeliosis are similar to those of extravascular immune-mediated haemolytic anaemia (KRAUSPENHAR et al., 2003; FIGHERA et al., 2010; FRANÇA et al., 2010). The complete blood count values of $L$. gymnocercus were within the reference values for domestic dogs and wild canids (JAIN, 1993; MATTOSO et al., 2012). The animal was slightly dehydrated, which could have masked the anaemia (RANDOLPH et al., 2010). On blood smears, regeneration indicators were not observed, although in $R$. vitalii experimentally infected dogs, the degree of anaemia varies, and reticulocytosis is often observed (SILVA et al., 2011). None of these signs were found in the L. gymnocercus. Low platelet count is a common sign in natural (FRANÇA et al., 2010) and experimental (SILVA et al., 2011) cases of canine rangeliosis. However, in our case, the low platelet count could also be related to trauma due to the injury sustained by the animal (MISCHKE, 2005). The animal had low total protein and albumin concentrations and high urea concentrations. Significant hypoproteinaemia associated with low albumin levels was detected in $R$. vitalii experimentally infected dogs (PAIM et al., 2013). However, because albumin is the most abundant protein in the serum, any reduction in this protein would result in a reduction in total protein (KANEKO et al., 1997). Because poor nutrition is common in wild animals, hypoproteinaemia may be related to malnutrition (KANEKO et al., 1997). The higher urea level without a concomitant rise in creatinine could be justified by dehydration of the animal (STOCKHAM \& SCOTT, 2011). The urine density was normal, suggesting a lack of renal damage.
In experimentally infected dogs, the levels of urea and creatinine did not differ from those in normal dogs (SILVA et al., 2011; COSTA et al., 2012), reinforcing the suspicion that dehydration was responsible for the elevation of urea. Soares et al. (2014) observed that in $C$. thous infected with $R$. vitalii, haematological and biochemical parameters were normal, with only a slight increase in serum total protein.

The other haemoprotozoan detected only by PCR, H. canis, is usually found in wild canids (CRIADO-FORNELIO et al., 2006; GIANNITTI et al., 2012), including those with concomitant rangeliosis (QUADROS et al., 2015). Criado-Fornelio et al. (2006) detected different Hepatozoon genotypes on wild canids from Brazil, including a H. americanum-related organism. Giannitti et al. (2012) studied a specimen of P. gymnocercus (i.e., L. gymnocercus) in southern Argentina and observed a genotype of Hepatozoon closely related to $H$. felis, including the presence of several cysts, resembling the "onion skin" cysts of $H$. americanum, in the skeletal and cardiac muscle of this animal. On the other hand, Quadros et al. (2015) diagnosed Hepatozoon sp. as 100\% identical to a corresponding sequence of $H$. canis from Rio Grande do Sul, Brazil.

The animal died as a consequence of injuries caused by being hit by a car and not as consequence of the parasitism. The results of the haematological exams, in addition with the presence of blood stages, allowed us to conclude that the animal was in the acute phase of infection. The few blood alterations could not be attributed to the infection, and further studies, like long term monitoring of infected animals, are needed to determine the impact of blood parasite infections on the health of wild canids. Quadros et al. (2015) reported clinical signs in L. gymnocercus naturally infected with $R$. vitalii. Thus, we speculate that an animal showing clinical signs of infection may be more prone to being hit by a car or captured. Moreover, in addition to their participation as disease-causing agents in endangered carnivores, Alvarado-Rybak et al. (2016) highlighted the importance of epidemiological studies of piroplasmid infections in wild carnivores and their roles as reservoirs of piroplasmids for domestic animals.

Further studies are needed to assess the epidemiology and pathogenic effects of these haemoparasites in the health of wild canids, and their role as reservoirs. There are few and isolated reports on $R$. vitalii infection of sylvatic canids. When it comes to the occurrence of this piroplasmid species in L. gymnocercus, the present study represents the third report, but the first to show the intraerythrocytic stages in the blood of wild canids. The prevalence of $R$. vitalii infection at the population level should be investigated, extending epidemiological studies to others Brazilian regions, with a higher number of animals. Although we could not determine the consequences of the infection on the animal health, long term monitoring infected animals, aiming at determining the effect of the parasites on their health, would be enlightening.

\section{References}

Alencar NX, Kohayagawa A, Santarém VA. Hepatozoon canis infection of wild carnivores in Brazil. Vet Parasitol 1997; 70(4): 279-282. http:// dx.doi.org/10.1016/S0304-4017(96)01119-3. PMid:9211653. 
Almeida AP, Souza TD, Marcili A, Labruna MB. Novel Ehrlichia and Hepatozoon agents infecting the crab-eating fox (Cerdocyon thous) in Southeastern Brazil. J Med Entomol 2013; 50(3): 640-646. http://dx.doi. org/10.1603/ME12272. PMid:23802461.

Altschul SF, Gish W, Miller W, Myers EW, Lipman DJ. Basic local alignment search tool. J Mol Biol 1990; 215(3): 403-410. http://dx.doi. org/10.1016/S0022-2836(05)80360-2. PMid:2231712.

Alvarado-Rybak M, Solano-Gallego L, Millán J. A review of piroplasmid infections in wild carnivores worldwide: importance for domestic animal health and wildlife conservation. Parasit Vectors 2016; 9(1): 538-557. http://dx.doi.org/10.1186/s13071-016-1808-7. PMid:27724937.

André MR, Adania CH, Teixeira RHF, Vargas GH, Falcade M, Sousa $\mathrm{L}$, et al. Molecular detection of Hepatozoon spp. in Brazilian and exotic wild carnivores. Vet Parasitol 2010; 173(1-2): 134-138. http://dx.doi. org/10.1016/j.vetpar.2010.06.014. PMid:20630658.

Carini A, Maciel J. Sobre a moléstia dos cães, chamada nambi-uvú, e o seu parasita (Rangelia vitalii). An Paul Med Cir 1914; 3(2): 65-71.

Conrad PA, Kjemtrup AM, Carreno RA, Thomford J, Wainwright K, Eberhard M, et al. Description of Babesia duncani n.sp. (Apicomplexa: Babesiidae) from humans and its differentiation from other piroplasms. Int J Parasitol 2006; 36(7): 779-789. http://dx.doi.org/10.1016/j. ijpara.2006.03.008. PMid:16725142.

Costa MM, França RT, Silva AS, Paim CB, Paim F, Amaral CH, et al. Rangelia vitalii: changes in the enzymes ALT, CK and AST during the acute phase of experimental infection in dogs. Rev Bras Parasitol Vet 2012; 21(3): 243-248. http://dx.doi.org/10.1590/S1984-29612012000300012. PMid:23070434.

Criado-Fornelio A, Ruas JL, Casado N, Farias NAR, Soares MP, Müller $G$, et al. New molecular data on mammalian Hepatozoon species (Apicomplexa: Adeleorina) from Brazil and Spain. J Parasitol 2006; 92(1): 93-99. http://dx.doi.org/10.1645/GE-464R.1. PMid:16629322.

Darriba D, Taboada GL, Doallo R, Posada D. jModelTest 2: more models, new heuristics and parallel computing. Nat Methods 2012; 9(8): 772. http://dx.doi.org/10.1038/nmeth.2109. PMid:22847109.

Eiras DF, Craviotto MB, Baneth G, Moré G. First report of Rangelia vitalii infection (canine rangeliosis) in Argentina. Parasitol Int 2014; 63(5): 729734. http://dx.doi.org/10.1016/j.parint.2014.06.003. PMid:24970768.

Fighera RA, Souza TM, Kommers GG, Irigoyen LF, Barros CSL. Patogênese e achados clínicos, hematológicos e anatomopatológicos da infecção por Rangelia vitalii em 35 cães (1985-2009). Pesq Vet Bras 2010; 30(11): 974-987. http://dx.doi.org/10.1590/S0100-736X2010001100012.

França RT, Silva AS, Loretti AP, Mazzanti CM, Lopes STA. Canine rangeliosis due to Rangelia vitalii: from first report in Brazil in 1910 to current day: a review. Ticks Tick Borne Dis 2014; 5(5): 466-474. http:// dx.doi.org/10.1016/j.ttbdis.2014.04.005. PMid:24950853.

França RT, Silva AS, Paim FC, Costa MM, Soares JF, Mazzanti CM, et al. Rangelia vitalii in dogs in southern Brazil. Comp Clin Pathol 2010; 19(4): 383-387. http://dx.doi.org/10.1007/s00580-010-1041-2.

Fredo G, Bianchi MV, Andrade CP, Souza SO, Leite-Filho RV, Bandinelli $\mathrm{MB}$, et al. Natural Infection of Wild Canids (Cerdocyon thous and Lycalopex gymnocercus) with the Intraendothelial Piroplasm Rangelia vitalii in Southern Brazil. J Wildl Dis 2015; 51(4): 880-884. http:// dx.doi.org/10.7589/2014-12-283. PMid:26251988.

Giannitti F, Diab SS, Uzal FA, Fresneda K, Rossi D, Talmi-Frank D, et al. Infection with a Hepatozoon sp. closely related to Hepatozoon felis in a wild Pampas gray fox (Lycalopex -Pseudalopex -gymnocercus) co-infected with canine distemper virus. Vet Parasitol 2012; 186(3-4): 497-502. http:// dx.doi.org/10.1016/j.vetpar.2011.11.006. PMid:22112977.

Hall TA. BioEdit: a user-friendly biological sequence alignment editor and analysis program for windows 95/98/NT. Nucleic Acids Symp Ser 1999; 41(2): 95-98.

Jain NC. The dog: normal hematology with comments on response to disease. In: Jain NC. Schalm's veterinary hematology. 4th ed. Philadelphia: Lea and Febiger; 1986. p. 103-125.

Jain NC. Comparative hematology of common domestic animals. In: Jain NC. Essentials of veterinary hematology. Philadelphia: Lea and Febiger; 1993. p. 19-54.

Kaneko JJ, Harvey JW, Bruss ML. Clinical biochesmistry of domestic animals. 5th ed. San Diego: Academic Press; 1997.

Krauspenhar C, Fighera RA, Graça DL. Anemia hemolítica em cães associada a protozoários. Medvep 2003; 1(4): 273-281.

Larkin MA, Blackshields G, Brown NP, Chenna R, McGettigan PA, McWilliam H, et al. Clustal W and Clustal X version 2.0. Bioinformatics 2007; 23(21): 2947-2948. http://dx.doi.org/10.1093/bioinformatics/ btm404. PMid: 17846036 .

Lemos TD, Cerqueira AMF, Toma HK, Silva AV, Corrêa RGB, Paludo $\mathrm{GR}$, et al. Detection and molecular characterization of piroplasms species from naturally infected dogs in southeast Brazil. Rev Bras Parasitol Vet 2012; 21(2): 137-142. http://dx.doi.org/10.1590/S1984-29612012000200012. PMid:22832754.

Loretti AP, Barros SS. Hemorrhagic disease in dogs infected with an unclassified intraendothelial piroplasm in southern Brazil. Vet Parasitol 2005; 134(3-4): 193-213. http://dx.doi.org/10.1016/j.vetpar.2005.07.011. PMid:16153781.

Mathew JS, Van Den Bussche RA, Ewing SA, Malayer JR, Latha BR, Panciera RJ. Phylogenetic relationships of Hepatozoon (Apicomplexa: Adeleorina) based on molecular, morphologic, and life-cycle characters. J Parasitol 2000; 86(2): 366-372. http://dx.doi.org/10.1645/00223395(2000)086[0366:PROHAA]2.0.CO;2. PMid:10780559.

Mattoso CRS, Catenacci LS, Beier SL, Lopes RS, Takahira RK. Hematologic, serum biochemistry and urinary values for captive Crabeating fox (Cerdocyon thous) in São Paulo state, Brazil. Pesq Vet Bras 2012 32(6): 559-566. http://dx.doi.org/10.1590/S0100-736X2012000600015.

Mischke R. Acute haemostatic changes in accidentally traumatised dogs. Vet J2005; 169(1): 60-64. http://dx.doi.org/10.1016/j.tvjl.2004.01.008 PMid:15683764.

Moreira MVL, Guimarães LB, Silva JF, Ocarino NM, Serakides R, Ecco R. Infecção por Rangelia vitalii em um cão em Minas Gerais. Arch Vet Sci 2013; 18(3): 637-639.

Paim FC, Silva AS, Paim CB, França RT, Costa MM, Duarte MMMF, et al. Serum proteinogram, acute phase proteins and immunoglobulins in dogs experimentally infected with Rangelia vitalii. Vet Parasitol 2013 192(1-3): 137-142. http://dx.doi.org/10.1016/j.vetpar.2012.09.036. PMid:23116898.

Paparini A, McInnes LM, Di Placido D, Mackereth G, Tompkins DM, Clough R, et al. Piroplasms of New Zealand seabirds. Parasitol Res 2014 113(12): 4407-4414. http://dx.doi.org/10.1007/s00436-014-4118-z. PMid:25204728.

Paparini A, Ryan UM, Warren K, McInnes LM, Tores P, Irwin PJ. Identification of novel Babesia and Theileria genotypes in the endangered marsupials, the woylie (Bettongia penicillata ogilbyi) and boodie (Bettongia 
lesueur). Exp Parasitol 2012; 131(1): 25-30. http://dx.doi.org/10.1016/j. exppara.2012.02.021. PMid:22433913.

Pestana BR. O nambyuvú (nota preliminar). Rev Soc Científ São Paulo 1910a; 5: 14-17.

Pestana BRO. Nambyuvú. Rev Méd São Paulo 1910b; 22: 423-426.

Quadros RM, Soares JF, Xavier JS, Pilati C, Costa JL, Miotto BA, et al 1. Natural Infection of the wild canid Lycalopex gymnocercus by the protozoan Rangelia vitalii, the agent of canine rangeliosis. JWildl Dis 2015; 51(3): 787-789. http://dx.doi.org/10.7589/2014-08-194. PMid:25932667.

Randolph JF, Peterson ME, Stokol T. Erythrocytosis and Polycythemia. In: Weiss DJ, Wardrop KJ. Schalm's veterinary hematology. 6th ed. Iowa: Blackwell Publishing; 2010. p. 162-166.

Ronquist F, Huelsenbeck JP. MrBayes 3: Bayesian phylogenetic inference under mixed models. Bioinformatics 2003; 19(12): 1572-1574. http:// dx.doi.org/10.1093/bioinformatics/btg180. PMid:12912839.

Ruas JL, Farias NAR, Soares MP, Brum JGW. Babesia sp. em Graxaim do Campo (Lycalopex gymnocercus) no Sul do Brasil. Arq Inst Biol 2003; 70(1): 113-114.

Saiki RK, Scharf S, Faloona F, Mullis KB, Horn GT, Erlich HA, et al. Enzymatic amplification of beta-globyn genomic sequences and restriction site analysis for diagnosis of sickle cell anemia. Science 1985; 230(4732): 1350-1354. http://dx.doi.org/10.1126/science.2999980. PMid:2999980.

Sambrook J, Fritsch EF, Maniatis T. Molecular cloning. New York: Cold Spring Harbor Laboratory Press; 1989.

Silva AS, França RT, Costa MM, Paim CB, Paim FC, Dornelles GL, et al. Experimental infection with Rangelia vitalii in dogs: Acute phase, parasitemia, biological cycle, clinical-pathological aspects and treatment. Exp Parasitol 2011; 128(4): 347-352. http://dx.doi.org/10.1016/j. exppara.2011.04.010. PMid:21570966.
Silveira JAG, D’Elia ML, Avelar IO, Almeida LR, Santos HA, Soares DFM, et al. Rangelia vitalii in a free-ranging maned wolf (Chrysocyon brachyurus) and co-infections. Int J Parasitol Parasites Wildl 2016; 5(3): 280285. http://dx.doi.org/10.1016/j.ijppaw.2016.09.003. PMid:27761403.

Smith TG. The genus Hepatozoon (Apicomplexa: Adeleina). J Parasitol 1996; 82(4): 565-585. http://dx.doi.org/10.2307/3283781. PMid:8691364.

Soares JF, Carvalho L, Maya L, Dutra F, Venzal JM, Labruna MB. Molecular detection of Rangelia vitalii in domestic dogs from Uruguay. Vet Parasitol 2015; 210(1-2): 98-101. http://dx.doi.org/10.1016/j. vetpar.2015.03.013. PMid:25843009.

Soares JF, Dall'Agnol B, Costa FB, Krawczak FS, Comerlato AT, Rossato BCD, et al. Natural infection of the wild canid, Cerdocyon thous, with the piroplasmid Rangelia vitalii in Brazil. Vet Parasitol 2014; 202(3-4): 156163. http://dx.doi.org/10.1016/j.vetpar.2014.02.058. PMid:24685025.

Soares JF, Girotto A, Brandão PE, Silva AS, França RT, Lopes ST, et al. Detection and molecular characterization of a canine piroplasm from Brazil. Vet Parasitol2011; 180(3-4): 203-208. http://dx.doi.org/10.1016/j. vetpar.2011.03.024. PMid:21489694.

Stockham S, Scott MA. Urinary system. In: Stockham S, Scott MA. Fundamentals of veterinary clinical pathology. 2nd ed. Ames: Blackwell; 2011. p. 415-494.

Tchaicka L, Eizirik E, Oliveira TG, Cândido JF Jr, Freitas TRO. Phylogeography and population history of the crab-eating fox (Cerdocyon thous). MolEcol2007; 16(4): 819-838. http://dx.doi.org/10.1111/j.1365294X.2006.03185.x. PMid:17284214.

Tree Bio. FigTree [online]. London; 2016 [cited 2017 Mar 6]. Available from: http://tree.bio.ed.ac.uk/ 